\title{
List otwarty Przewodniczącego Zarządu Głównego Polskiego Towarzystwa Onkologicznego
}

Od kilku miesięcy toczy się w mediach polemika dotycząca przyszłości Instytutu Onkologii. Uważam, że należy ją zakończyć, bowiem dalsza licytacja racji do niczego nie prowadzi. Obecne różnice poglądów nie powinny przekreślać możliwości podjęcia wspólnych działań dla dobra polskiej onkologii. Z satysfakcją przyjmuję pewne zbliżenie poglądów stron i wierzę, że kontrowersyjne kwestie można będzie rozstrzygnąć w partnerskiej dyskusji. Naprawdę szkoda czasu na dalsze polemiki.

PTO, w szerokiej współpracy z innymi towarzystwami naukowymi, organizacjami pacjenckimi i ekspertami, rozpoczyna prace nad strategicznym programem rozwoju polskiej onkologii. Jego powodzenie zależy od zaangażowania całego środowiska onkologicznego. Zapraszamy więc do współpracy wszystkie osoby, organizacje i instytucje, które chcą uczestniczyć w tym ważnym przedsięwzięciu. Tylko w ten sposób doprowadzimy do poprawy warunków leczenia polskich chorych. O szczegółach podejmowanych działań będziemy informowali na portalu naszego Towarzystwa.

Prof. Jacek Jassem 